\title{
A practical approach to patient with Young-onset dementia
}

\author{
Marina Boban ${ }^{1,2}$ \\ School of Medicine, University of Zagreb, Šalata 2, Zagreb, Croatia \\ ${ }^{2}$ Department of Cognitive Neurology, Referral Center for Cognitive Neurology and Neurophysiology, University Hospital \\ Centre, Kišpatićeva 12, Zagreb, Croatia
}

OPEN ACCESS

Correspondence: Marina Boban marina.boban@mef.hr orcid.org/0000-0002-3109-050X

This article was submitted to RAD CASA - Medical Sciences as the original article

Conflict of Interest Statement: The authors declare that the research was conducted in the absence of any commercial or financial relationships that could be construed as a potential conflict of interest.

Received: 28 April 2021 Accepted: 7 May 2021 Published: 15 June 2021

Citation:

Boban M. A practical approach to patient with Young-onset dementia RAD CASA - Medical Sciences. 547=54-55 (2021): 86-92 DOI: https://dx.doi.org/10.21857/ mwo1vcjl7y

Copyright (C) 2021 Boban M. This is an open-access article distributed is an open-access article distributed
under the terms of the Creative Commons Attribution License (CC BY). The use, distribution or reproduction in other forums is permitted, provided the original author(s) and the copyright owners(s) are credited and that the original publication in this journal is cited, in accordance whit accepted is cited, in accordance whit accepted or mic practice. No use, distribution or reproduction is permitted which
does not comply with these terms.

\begin{abstract}
:
"Young-onset dementia" (YOD) includes clinical presentations of dementia with the onset before age of 65. There are several important clinical differences between much more frequent late onset dementia (LOD) and YOD syndromes. First, YOD has much wider range of different aetiologies comparing to LOD. Among all possible aetiologies, treatable/potentially reversible causes are much more common in YOD then in LOD. There is also significantly higher prevalence of inherited dementias in younger age-groups. Furthermore, atypical cognitive (non-amnestic) presentations of common degenerative dementias (e. g. Alzheimer's disease) are more frequent in YOD. Therefore, routine cognitive evaluation using standard screening tests (e.g. MMSE) may be insufficient. YOD is more often accompanied by neurological and systemic features (dementia plus syndromes) and the identification of these features can aid the diagnosis.

Based on these specificities of YOD, diagnostic approach is always challenging. Therefore, a thorough neurocognitive assessment and a structured and rational diagnostic approach is mandatory to ensure early diagnosis and treatment.
\end{abstract}

Keywords: Alzheimer's disease; Dementia; Presenile dementia, Young-onset dementia

\section{SAŽETAK:}

DEMENCIJE S POČEKOM U RANOJ ŽIVOTNOJ DOBI-PRAKTIČNI PRISTUP OBOLJELOM

Demencije s počekom u ranoj životnoj dobi (engl. Young-onset dementia, YOD) označavaju pojavu demencije prije 65. godine života. Postoji nekoliko važnih kliničkih razlika između mnogo učestalijih demencija koje počinju iza 65. godine života (engl. Late-onset dementia, LOD) i YOD. Prvo, YOD ima mnogo širi raspon različitih uzroka u usporedbi s LOD-a. Među svim mogućim etiologijama, kod demencija ranog početka mnogo su češći izlječivi/potencijalno reverzibilni uzroci demencije. Također je znatno češća nasljedna komponenta u demencijama s početkom u mlađim dobnim skupinama. Nadalje, atipične kognitivne (ne-amnestičke) prezentacije uobičajenih degenerativnih demencija (npr. Alzheimerove bolesti) češće su u YOD. Stoga kognitivna procjena pomoću standardnih screening testova (npr. MMSE testa) može biti neadekvatna. YOD je češće popraćen neurološkim i sistemskim simptomima i znakovima (demencija plus sindromi), a prepoznavanje tih značajki može pomoći u dijagnozi. $\mathrm{Na}$ temelju tih specifičnosti YOD-a, dijagnostički pristup uvijek predstavlja veliki izazov. Stoga je u pristupu oboljelom potrebna detaljna neurokognitivna procjena te strukturiran i racionalan dijagnostički pristup kako bi se osigurala rana dijagnoza i liječenje.

KLJUČNE RIJEČI: Alzheimerova bolest; demencija; presenilna demencija 


\section{INTRODUCTION}

Decades ago, the term "presenile dementia" has been replaced with terms "young(er)/early-onset dementia" (YOD) that include patients with early onset of dementia (before age of 65). The diagnosis of YOD presents a particular challenge for cognitive neurologist and, although not so common among all dementia cases (approximately $8 \%$ of all dementia cases) $)^{1,2}$, it is recognised as a growing socioeconomic problem, since it affects working population. While the main and predominant cause of dementia in older age is sporadic Alzheimer's disease (AD), YODs have much wider range of different aetiologies with higher percentage of potentially curable causes and a higher prevalence of inheritance ${ }^{1,2}$. Due to younger age, broad differential diagnosis, common non-amnestic cognitive presentations that can be missed by standard screening tests and frequent presence of other neurological and systemic symptoms, diagnostic approach is always challenging. Therefore, a structured and rational diagnostic approach is necessary to ensure early treatment and prevent progression of the disease if possible ${ }^{1-4}$. The intent of this short review is to emphasize specific clinical features of YOD group and to provide current evidence for complex diagnostic approach to patient with YOD.

\section{Aetiology of YOD}

The aetiology of YODs is broad (Table 1.) (adapted from ${ }^{5}$ ). $\mathrm{AD}$, vascular cognitive impairment (VCI), frontotemporal lobar degeneration (FTLD) and diffuse Lewy body dementia (DLBD) are the most common causes of dementia both in elderly and in younger patients (Figure 1.) ${ }^{6}$. If the presentation of dementia is before age of 45 , neurodegenerative dementia accounts for $30 \%$ of cases (with a rare presentation of AD), autoimmune and inflammatory causes account for $20 \%$, and nearly in $20 \%$ of dementia cases the cause remains unknown ${ }^{7}$.

Table 1. Etiology of young-onset dementia (according to Sampson et al. $)^{5}$

Primary neurodegenerations

Alzheimer's disease

Frontotemporal lobar degeneration

Dementia with Lewy bodies

Multiple system atrophy

Corticobasal degeneration

Parkinson's disease

Progressive supranuclear palsy

$\underline{\text { Vascular cognitive impairment }}$

Prion

Creutzfeldt-Jakob disease

Inflammatory

Vasculitis associated with systemic disorders* Primary angiitis of central nervous system* Neurosarcoidosis*

Behçet's disease*

Multiple sclerosis

Neoplastic

Tumours (especially frontal lobe)*

Paraneoplastic

Limbic encephalitis*

"Steroid-responsive" encephalopathies Hashimoto's encephalopathy*
Infections

Tuberculosis/fungal/viral meningitis*

HIV*

Whipple's disease

Neuroborreliosis*

Neurosyphilis*

Subacute sclerosing panencephalitis

Progressive multifocal leukoencephalopathy

Endocrine and metabolic

Endocrinopathies*

Nutritional deficiency*

Uraemia*

Hepatic encephalopathy*

Wilson's disease*

Epilepsy*

$\underline{\text { Alcohol }}$

$\underline{\text { Toxic (carbon monoxide, lead, prescribed drugs) }}$

Post-irradiation

Hydrocephalus*

Chronic subdural haematoma*

Obstructive sleep apnea*

*potentially treatable cause 


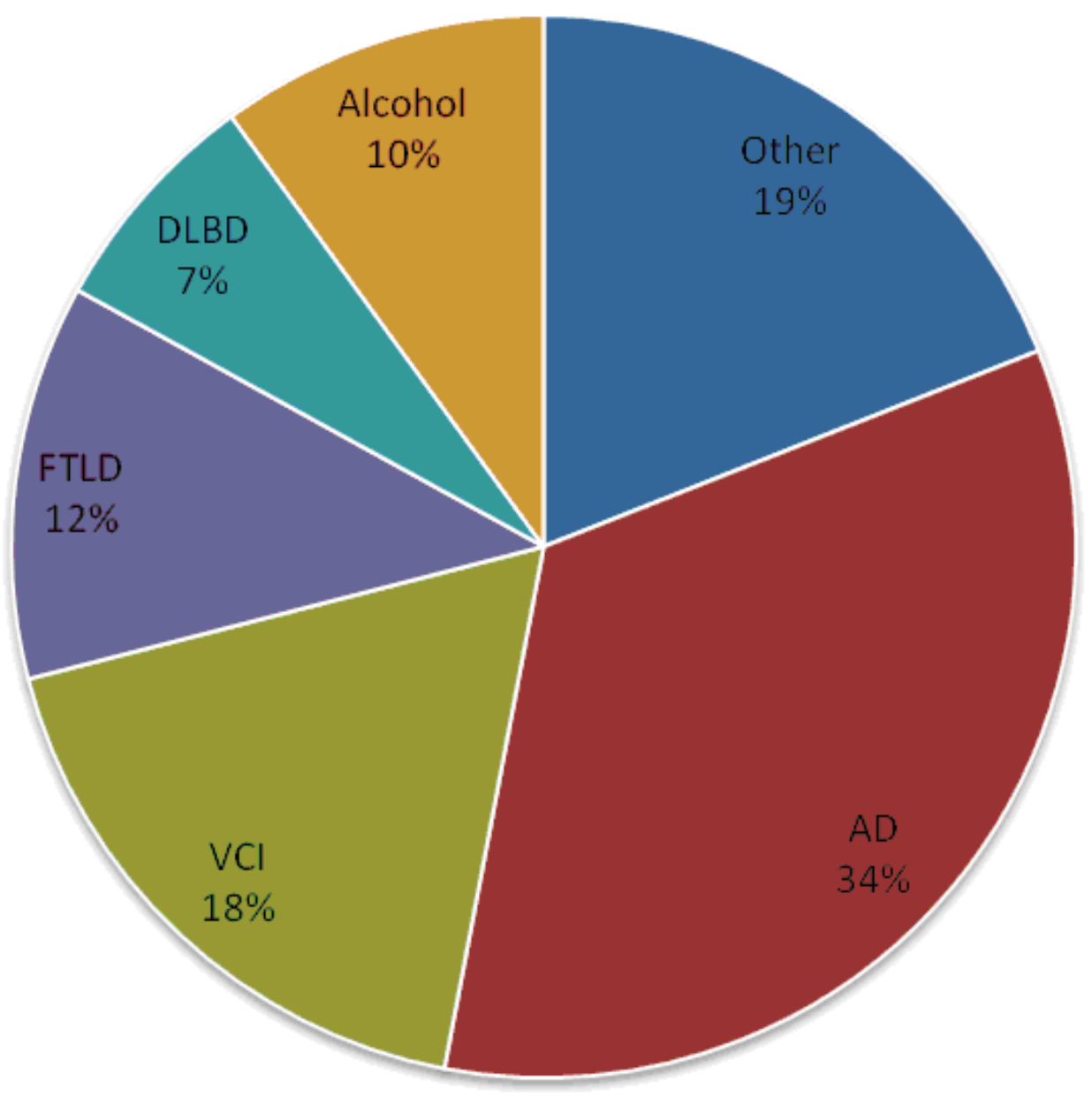

Figure 1. Epidemiology of young-onset dementia (according to Harvey et al.) ${ }^{6}$

\section{A PRACTICAL APPROACH}

The clinical assessment of a patient with dementia should be the same regardless of age. However, having a wide range of potentially curable causes, a structured and more detailed approach is essential. The first step is to obtain a detailed history (the onset and course of the disease, initial symptoms, personality and mood changes, changes in everyday activities and lifestyle, former and present psychiatric diseases). That information should best be gathered from an informant who knows the patient well, because the information given by the patient is often not reliable. The following steps include a thorough general and neurological examination and neurocognitive assessment that may narrow the differential diagnosis ${ }^{1-5}$. Red flag clinical presentations that should alert neurologist to perform cognitive screening in middle-aged people are: treatment-resistant depression or anxiety, especially if there are subjective cognitive complaints; patients presenting with memory or other cognitive problems, especially with positive family history of young onset dementia; concern about the patient's cognition from close family member; behaviour changes inconsistent with the premorbid personality; 5 or more years of heavy alcohol or substance abuse; HIV-positive status; progression of neurological problems; family history of YOD and chronic systemic disease known to cause dementia ${ }^{1}$.

\section{PATTERN OF THE COGNITIVE DEFICIT}

YOD may often initially be presented with non-amnestic deficits, which can be missed with routine screening tests (e.g. Mini Mental State Examination (MMSE) ${ }^{8}$, already validated for Croatian population ${ }^{9}$ ); therefore, a thorough cognitive assessment with evaluation of each cognitive domain (i.e. memory, speech, executive and perceptual functions, praxia and other) is essential for detecting cognitive deficits and determining the exact pattern of cognitive dysfunction. Moreover, it is important to recognise different types of cognitive impairment within cognitive domain, e.g. in the memory domain, impairment of episodic memory, distinctive for $\mathrm{AD}$, should be distinguished from semantic memory impairment, characteristic for semantic dementia (SD) ${ }^{10}$. The patient's history (both acquired from the patient himself and people close to him) about everyday activities, changes in lifestyle and personality can direct to the pattern of cognitive deficit ${ }^{1-5}$. A useful distinction between cortical and subcortical dementias can be made at the beginning of the evaluation. Patients with cortical dementias can differ in the pattern of cognitive impairment early at the onset of symptoms (e.g. effortful, non-fluent speech in progressive non-fluent aphasia (PNFA), visuoperceptual and visuospatial deficits in posterior cortical atrophy (PCA) or loss of semantic knowledge in SD) with relative preservation 
of psychomotor speed. By contrast, subcortical dementias (e.g. brain small vessel disease, dementia involving basal ganglia) is characterised by profound slowing of psychomotor speed ${ }^{11}$, executive dysfunction, and impairment of memory retrieval (free recall) with preservation of guided memory retrieval (cued recall) and is commonly accompanied by additional neurological and/ or systematic features (motor weakness, sensory loss, changes in myotatic reflexes etc.).

Low score on verbal fluency test (the patient is asked to name as many words starting with an assigned letter in given time) might be a useful non-specific indicator of cognitive dysfunction ${ }^{12}$ and can additionally narrow the differential diagnosis ${ }^{13}$.

Episodic memory impairment, besides in $\mathrm{AD}$, can be a dominant feature of temporal lobe epilepsy, limbic encephalitis, paraneoplastic syndrome, autoimmune connective tissue diseases etc. Parietal (visuospatial or visuoperceptual deficits, dyslexia, dysgraphia, dyscalculia, or apraxia) or occipital (visual disorientation and impaired early visual processing) dysfunction is typical of PCA, but can also occur in patients suffering from DLBD, corticobasal degeneration (CBD), or prion disease. Prominent frontal deficits (executive dysfunction, personality change, disinhibition, apathy, lack of empathy, rigid thinking, obsessive-compulsive behaviour and development of sweet cravings) are characteristic features of frontotemporal variant of frontotemporal lobar degeneration (fvFTLD), but may also occur in AD, VCI, progressive supranuclear palsy (PSP), Huntington's disease (HD) and in some rare metabolic and inherited diseases which affect frontal white matter or basal ganglia. Problems with speech production (with phonemic and grammatical errors) typically occur in PNFA, but can also be seen in CBD, PSP and AD, while trouble with naming and understanding meaning of spoken words is suggestive of $\mathrm{SD}^{4}$.

\section{PSYCHIATRIC EVALUATION}

Every patient with cognitive impairment should undergo a thorough evaluation of psychiatric symptoms (changes in behaviour, delusions and hallucinations, mood changes, neurovegetative disorders or personality changes). Behavioural symptoms are a characteristic initial sign of fvFTLD when the MMSE score may be normal. Some dementias can initially be presented with delusions (false belief that is against the reality) and hallucinations (DLBD) ${ }^{1-5}$. Depressive mood swings as well as depression are common in patients suffering from dementia. Other significant psychiatric disorders are sleep disturbances (hyposomnia, hypersomnia, the day-night cycle reversal, REM sleep behaviour disorder in patients with DLBD etc.) and changes in sexual behaviour. A craving for sweets is a typical sign of fvFTLD ${ }^{10}$. Observing the patient's behaviour during the examination can also be very useful, e.g. psychomotor slowing in patients with subcortical syndrome, impulsive behaviour and disinhibition in patients with frontal cortical syndrome. Additionally, patients with $\mathrm{AD}$ preserve the social appearance, but, during the interview, often they tend to turn to their partner to answer the questions (the "head turning" sign) ${ }^{10}$.

\section{NEUROLOgicAL EXAMINATION}

Many of the YODs are accompanied with additional neurological and/or systemic features (dementia plus syndromes). Therefore, careful neurological examination is essential in YOD (compared to late onset forms) to narrow possible differential diagnosis. Although isolated cognitive decline is characteristic for $\mathrm{AD}$ and FTLD, in YOD the early stage of $\mathrm{AD}$ can be accompanied with fine myoclonus ${ }^{14}$, while FTLD can be presented with fasciculations mostly restricted to the deltoid and triceps muscles as well as positive primitive reflexes ${ }^{15}$. The presence of parkinsonian symptoms may suggest Parkinson's disease (PD), DLBD, but also other aetiologies such as VCI, PSP, CBD, prion disease, $\mathrm{HD}$, Wilson's disease, neuroacanthocytosis, neurosyphilis, spinocerebellar ataxia (SCA) and other ${ }^{4}$. Ataxia may occur in VCI, vitamin $\mathrm{B} 12$ or vitamin $\mathrm{E}$ deficiency, exposure to toxins, especially alcohol, paraneoplastic syndrome, multiple sclerosis (MS), coeliac disease, Wilson's disease, prion disease, SCA and other. Pyramidal signs may suggest VCI, MS, vitamin B12 deficiency, SCA, mitochondrial or prion disease, neurosyphilis, and other. Dystonia and choreoathetosis may suggest HD, CBD, Wilson's disease, prion disease, SCA, dentatorubral-pallidoluysian atrophy (DRPLA), and other. „Alien limb“ phenomenon is characteristic for CBD, but can also occur in neurosyphilis ${ }^{16}$. Various different ophthalmologic manifestations may occur: retinitis pigmentosa suggests mitochondrial disorders; optic atrophy or macular degeneration occurs in MS, neurosarcoidosis, vitamin B12 deficiency; retinal microangiopathy is common in diabetes mellitus and hypertension (which are risk factors for developing VCI) and in vasculitis; supranuclear palsy or gaze palsy suggest PSP, CBD, mitochondrial disorders; Kayser-Fleicher ring is a pathognomic sign for Wilson's disease; infection and dryness of the eyes suggest autoimmune connective tissue disease. Seizures may occur in $\mathrm{AD}$ and VCI or may be a result of a former stroke ${ }^{4}$. Marche a petit pas, i.e., parkinsonism affecting lower limbs accompanied with parkinsonian gait (small shuffling steps), with upright stance and normal arm swing, is a characteristic of cerebral small vessel disease. The classic Hakim's triad (gait disturbance, urinary incontinence, and cognitive decline) is typical for normal pressure hydrocephalus ${ }^{4}$.

\section{GenERAL EXAMINATION}

YOD are more often accompanied with additional systemic features (dementia plus syndromes). Certain findings, signs, symptoms, and information from patient's history can indicate the aetiology of YOD. Thus, examination of the fundi and blood pressure are essential for recognition of vascular disease and vascular risk factors. When suspecting paraneoplastic syndrome, 
breasts, testes, and other potential cancer sites should be examined. Skin findings may suggest an underlying vasculitis or connective tissue disorder. Cardiac patients (especially patients with arrhythmias or patients who have recovered from a heart attack) have a higher risk for developing VCI. Some conditions like Whipple's disease or coeliac disease manifest with gastrointestinal disturbance. Liver disease can also lead to cognitive decline (subacute haptic encephalopathy) $)^{1-5,17}$.

\section{NeUROPSYCHOLOGICAL ASSESSMENT}

Neuropsychological evaluation is essential in majority of patient with YOD. Validated psychological tests enable an objective and quantitative insight of the extent and pattern of cognitive impairment in an affected subject ${ }^{1-5}$. Due to their high sensitivity, neuropsychological tests enable recognition of the cognitive decline in the early stages of the disease when screening tests are still deficient. Furthermore, neuropsychological tests can evaluate the patient's premorbid functioning, while repeated assessments can help monitor the progression/recovery of cognitive deficits $^{1-5,10,12}$.

\section{FURTHER INVESTIGATIONS}

The approach to patients suffering from dementia, regardless of age, should at the beginning be directed towards recognising treatable causes (marked with asterisks in Table 1.) 5 . In YOD, this is of the utmost importance because, in this age group potentially reversible causes are more frequent ${ }^{1-5}$. Furthermore, wider differential diagnosis in younger patients requires more detailed evaluation. As it is impossible to define an unique diagnostic schema, every patient should be approached with an individual plan based on the patient's history, symptoms and findings (e.g. evident inherited component requires genotyping early in assessment; rapidly progressive dementia or signs of systemic disease urge a serum antibody screen, i.e., a screen for autoantibodies, antineural antibodies or antibodies associated with limbic encephalitis). According to the American Academy of Neurology and European Federation of Neurological Societies every patient with YOD should undergo neuroimaging (preferably brain MRI) and cerebrospinal fluid (CSF) examination ${ }^{3.4,18,20}$. Additional not frequently used tests (e.g genetic testing, metabolic profiling, testing the activity of white cell enzymes and tissue biopsy) should be considered only in specific cases. Despite extensive evaluation, the aetiology in YOD often remains unknown even in specialized memory clinics. Those patients should be monitored and frequently re-evaluated.

MRI is the first line diagnostic procedure in YOD. In primary neurodegenerative dementias it can show specific localized distribution of cortical atrophy (e.g. left temporal lobe atrophy in SD (Fig. 2), posterior lobe atrophy in PCA (Fig. 3), frontal lobe

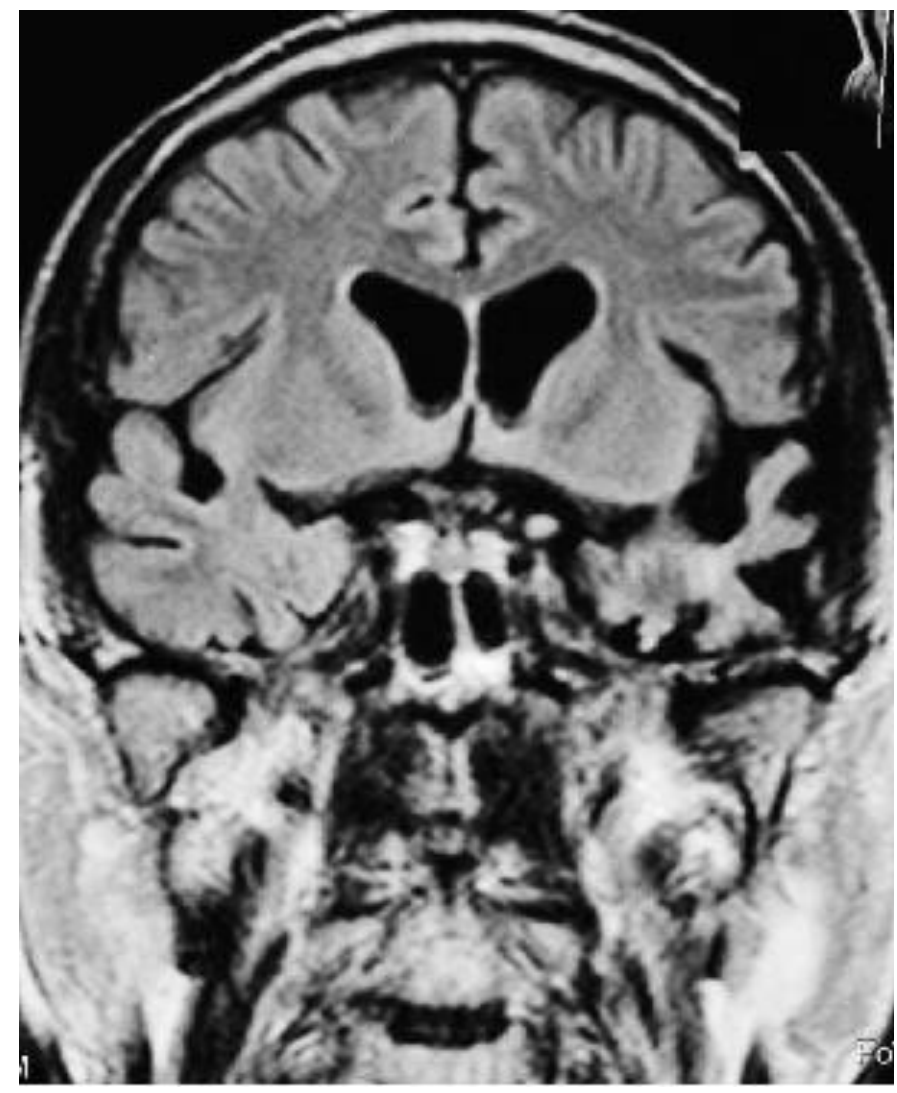

Figure 2. Brain MRI scan of a 64-year-old patient with semantic dementia showing predominant left temporal lobe atrophy. Coronal view.

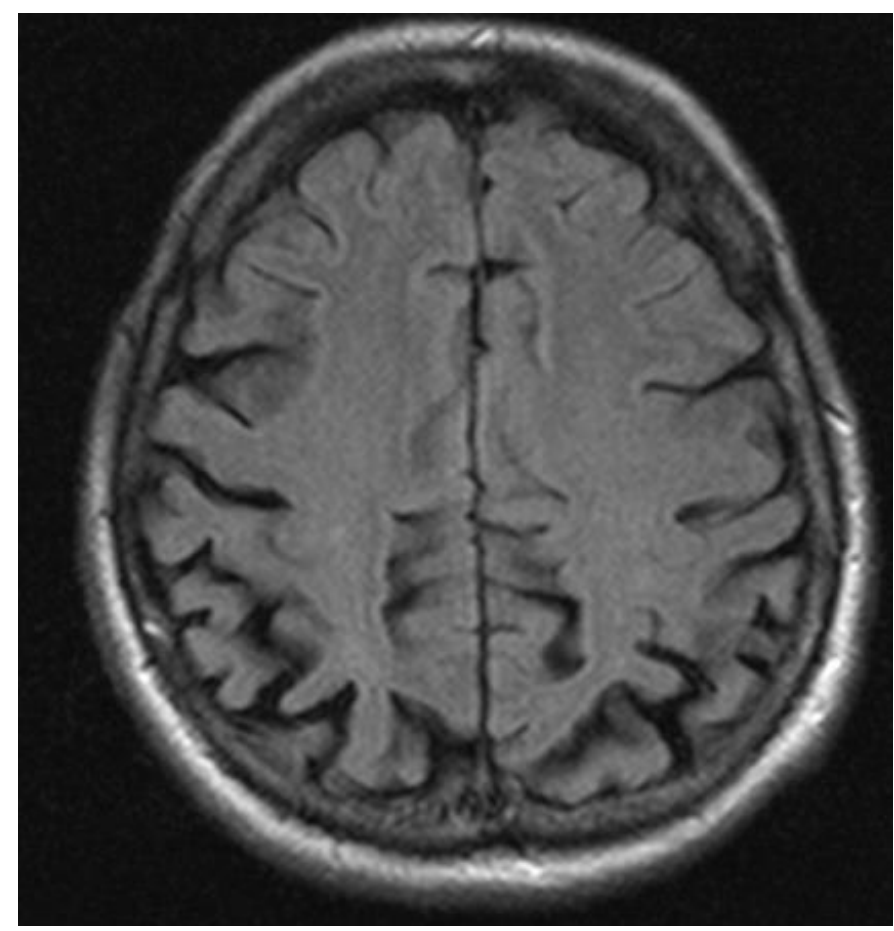

Figure 3. Brain MRI scan of a 66-year-old patient with posterior cortical atrophy showing predominant parietal lobe atrophy. Axial view. 
atrophy in fvFTLD etc.). It may also enable quantitative (using volumetric MRI) and semiquantitative (using different scales, such as Scheltens scale ${ }^{21}$ ) assessment of degree of atrophy (e.g. assessment of hippocampal atrophy in $\mathrm{AD}$ patients) with the possibility of monitoring of progression ${ }^{1-5}$.

Genetic testing can be done to confirm primary neurodegenerative dementias (e.g. mutations in amyloid precursor protein gene $(A P P)$ and presenilin genes (PSEN1 and PSEN2) in AD or mutations in MAPT, GRN and C9orf72 genes in FTLD syndrome ${ }^{22}$ ). Nowadays, genetic testing for most primary neurodegenerative diseases are available for in Croatia. Due to high costs of genotyping and presence of many mutations, for some aetiologies, it is still preferable to establish the diagnosis on the basis of a metabolic profile (e.g. increased copper excretion and low ceruloplasmin in Wilson's disease) or direct enzyme assay in leukocytes in metabolic disorders presented in adulthood ${ }^{3-4}$.

Metabolic and molecular brain imaging (especially positron emission tomography (PET) using different ligands such as fluorodeoxyglucose (FDG) or Pittsburgh B compound (PiB)) have an important role in the assessment of highly selected patients with YOD, and it is available only in highly specialized centres. In patients with $\mathrm{AD}$ temporo-parietal hypometabolism (and hypoperfusion) can be found on FDG PET (and SPECT) imaging of the brain, but this is rarely of greater ancillary value comparing to MRI finding of hippocampal atrophy alone ${ }^{3}$. By contrast, hypometabolism on FDG PET may be seen in patients with fvFTLD even before MRI shows signs of atrophy ${ }^{3}$. PET imaging with $\mathrm{PiB}$ can show in vivo the presence of cerebral amyloid depositions in patients with $\mathrm{AD}$ and amyloid angiopathy ${ }^{3-4}$. Currently, all these methods are available in Croatia. Costs of PET imaging with PiB tracer is covered by health insurance, but only for selected patients with YOD.

In suspicion of paraneoplastic syndromes, the whole-body PET scan might be needed in order to detect primary tumour ${ }^{1-5}$. Electroencephalography (EEG) is of value in various encephalopathies, prion diseases and subacute sclerosing panencephalitis (showing characteristic changes of periodic complexes) ${ }^{3-4}$. Early slowing or loss of alpha rhythm is a feature of $\mathrm{AD}$, in contrast to FTLD, where the alpha rhythm is relatively preserved ${ }^{3}$.
Examination of the CSF can exclude inflammatory and infectious processes in the central nervous system. In the last decade lots of biomarkers emerged that are valuable ancillary tests for confirmation of the diagnosis of dementia (e.g. the presence of 14-3-3 protein with very high concentrations of tau protein is supportive of a diagnosis of Creutzfeldt-Jakob disease (CJD); decreased amyloid $\beta_{1-42}$ and increased phosphorylated and total tau proteins have good sensitivity and specificity for $\mathrm{AD}$ and are also predictive for conversion of mild cognitive impairment to $\mathrm{AD})^{3,18-20}$. Thus, lumbar puncture and measuring three aforementioned CSF biomarkers (amyloid $\beta_{1-42}$, phosphorylated and total tau proteins) is included in recommendations for diagnosing of all stages of $\mathrm{AD}$ (presymptomatic, mild cognitive impairment and overt dementia) from the National Institute on Aging and the Alzheimer's Association workgroup ${ }^{18-20}$ Currently, CSF biomarkers for $\mathrm{AD}$ are available in Croatia. Biomarkers for other neurodegenerative diseases are still in the research phase. At the end, tissue biopsy might be needed to establish the diagnosis in rare situations (e.g. skin biopsy when suspecting Cerebral Autosomal Dominant Arteriopathy with Sub-cortical Infarcts and Leukoencephalopathy (CADASIL), muscle biopsy including histochemistry and respiratory enzyme analysis can confirm a mitochondrial disorder, tonsillar biopsy in patients with suspected variant $\mathrm{CJD}^{23}$, brain biopsy when suspecting cerebral vasculitis ${ }^{24}$, small bowel biopsy for confirming the diagnosis of Whipple's or coeliac disease etc. $)^{1-5}$.

\section{CONCLUSION}

YODs have much wider range of different aetiologies. In contrast to LODs, treatable causes and positive inherited background are more common in YOD. Atypical presentations of common degenerative dementias are more frequent then in LOD. Therefore, routine cognitive evaluation using standard screening tests (e.g. MMSE) is usually insufficient, since non-amnestic deficits, more often found in these patients can easily be missed. Therefore, a thorough neurocognitive assessment and a structured and rational diagnostic approach is mandatory to ensure early treatment and prevent progression of the disease. 


\section{REFERENCES:}

1. Draper B, Withall A. Young onset dementia. Intern Med J 2016;46:779-86.

2. Pawlowski M, Johnen A, Duning T. Früh beginnende Demenzen [Young onset dementia]. Nervenarzt. 2020;91:93645 .

3. Rossor MN, Fox NC, Mummery CJ, Schott JM, Warren JD. The diagnosis of young-onset dementia. Lancet Neurol 2010;9:793-806.

4. Ridha B, Josephs KA. Young-onset dementia. A Practical Approach to Diagnosis. Neurologist 2006;12:2-13.

5. Sampson EL, Warren JD, Rossor MN. Young onset dementia. Postgrad Med J 2004;80:125-39.

6. Harvey RJ, Skelton-Robinson M, Rossor MN. The prevalence and causes of dementia in people under the age of 65 years. J Neurol Neurosurg Psychiatr 2003;74:1206-9.

7. Kelley BJ, Boeve BF, Josephs KA. Young-onset dementia: demographic and etiologic characteristics of 235 patients. Arch Neurol 2008;65:1502-8.

8. Folstein MF, Folstein SE, McHugh PR. "Mini-mental state". A practical method for grading the cognitive state of patients for the clinician. J Psychiatr Res 1975;12:189-98.

9. Boban M, Malojčić B, Mimica N, et al. The reliability and validity of the mini-mental state examination in the elderly Croatian population. Dement Geriatr Cogn Disord 2012;33:385-92.

10. Harvey R, Fox NC, Rossor MN. Dementia Handbook. Martin Dunitz Ltd, London, 1999.

11. Albert ML, Feldman RG, Willis AL. The 'subcortical dementia' of progressive supranuclear palsy. J Neurol Neurosurg Psychiatry 1974;37:121-30.

12. Griffiths TD, Welch JL. How to do it: use a diagnostic neuropsychology service properly. Pract Neurol 2003;3:170-5.

13. Boban M, Malojčić B, Mimica N, Vuković S, Zrilić I. The Frontal Assessment Battery in the differential diagnosis of dementia. J Geriatr Psychiatry Neurol 2012;25:201-7.

14. Forstl H, Burns A, Levy R, Cairns N, Luthert P, Lantos P. Neurologic signs in Alzheimer's disease: results of a prospective clinical and neuropathologic study. Arch Neurol 1992; $49: 1038-42$.
15. McKhann GM, Albert MS, Grossman M, et al. Clinical and pathological diagnosis of frontotemporal dementia: report of the Work Group on Frontotemporal Dementia and Pick's Disease. Arch Neurol. 2001;58: 1803-9.

16. Benito-Leon J, Alvarez-Linera J, Louis ED. Neurosyphilis masquerading as corticobasal degeneration. Mov Disord 2004;19:1367-70.

17. Boban M, Malojčić B. Young-onset dementia and MRI changes in a patient with subclinical liver cirrhosis due to chronic hepatitis C. Translational Neuroscience 2011;2:3602.

18. Sperling RA, Aisen PS, Beckett LA, et al. Toward defining the preclinical stages of Alzheimer's disease: recommendations from the National Institute on Aging and the Alzheimer's Association workgroup. Alzheimers Dement 2011;7:280-92.

19. Albert MS, DeKosky ST, Dickson D, et al. The diagnosis of mild cognitive impairment due to Alzheimer's disease: recommendations from the National Institute on Aging and Alzheimer's Association workgroup. Alzheimers Dement 2011;7:270-9.

20. McKhann GM, Knopman DS, Chertkow H, et al. The diagnosis of dementia due to Alzheimer's disease: recommendations from the National Institute on Aging and the Alzheimer's Association workgroup. Alzheimers Dement 2011;7:263-9.

21. Scheltens P, van de Pol L. Atrophy of medial temporal lobes on MRI in probable Alzheimer's disease and normal ageing: diagnostic value and neuropsychological correlates. J Neurol Neurosurg Psychiatry 2012;83:1038-40.

22. Goldman JS, Van Deerlin VM. Alzheimer's Disease and Frontotemporal Dementia: The Current State of Genetics and Genetic Testing Since the Advent of Next-Generation Sequencing. Mol Diagn Ther 2018;22:505-13.

23. Heath CA, Cooper SA, Murray K, et al. Validation of diagnostic criteria for variant Creutzfeldt-Jakob disease. Ann Neurol 2010;67:761-70.

24. Scolding NJ. Central nervous system vasculitis. Semin Immunopathol 2009;31:527-36. 
